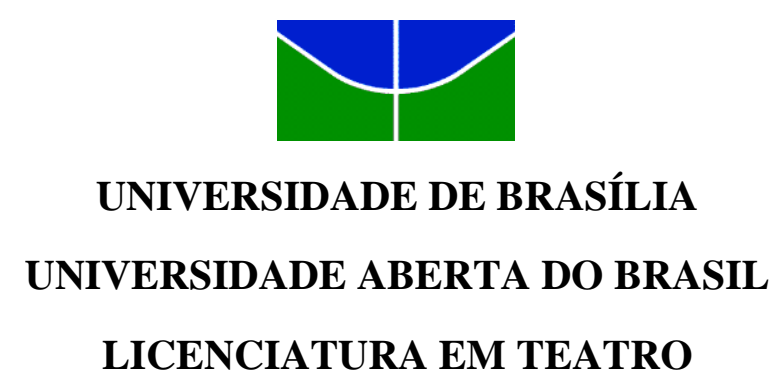

\title{
A LINGUAGEM TEATRAL NO DESENVOLVIMENTO ESCOLAR DO ALUNO COM DÉFICIT DE APRENDIZAGEM
}

ERDINACHELE MACHADO SALATIEL 


\author{
Universidade de Brasília \\ Universidade Aberta do Brasil \\ Licenciatura em Teatro
}

\title{
A LINGUAGEM TEATRAL NO DESENVOLVIMENTO ESCOLAR DO ALUNO COM DÉFICIT DE APRENDIZAGEM
}

\section{Erdinachele Machado Salatiel}

Trabalho de conclusão do Curso de Teatro, com habilitação em Licenciatura, no Departamento de Artes Cênicas do Instituto de Artes da Universidade de Brasília.

Orientador: Prof. Ms. Tiago de Brito Cruvinel 
ERDINACHELE MACHADO SALATIEL

A LINGUAGEM TEATRAL NO DESENVOLVIMENTO ESCOLAR DO ALUNO COM DÉFICIT DE APRENDIZAGEM

Trabalho de conclusão de curso aprovado, apresentado a UnB - Universidade de Brasília, no Instituto de Artes, Departamento de Artes Cênicas- CEN como requisito para obtenção do título de Licenciatura em Teatro com nota final igual a sob a orientação do (a) professor (a) Ms. Tiago de Brito Cruvinel.

Ipatinga-MG, 22 de novembro de 2014.

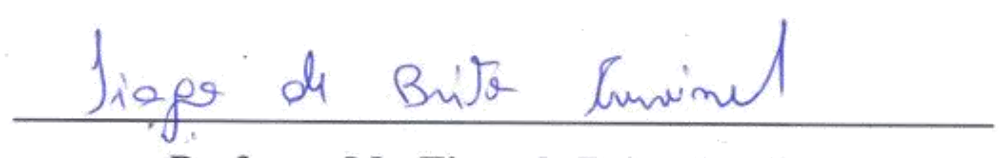

Professor Ms. Tiago de Brito Cruvinel
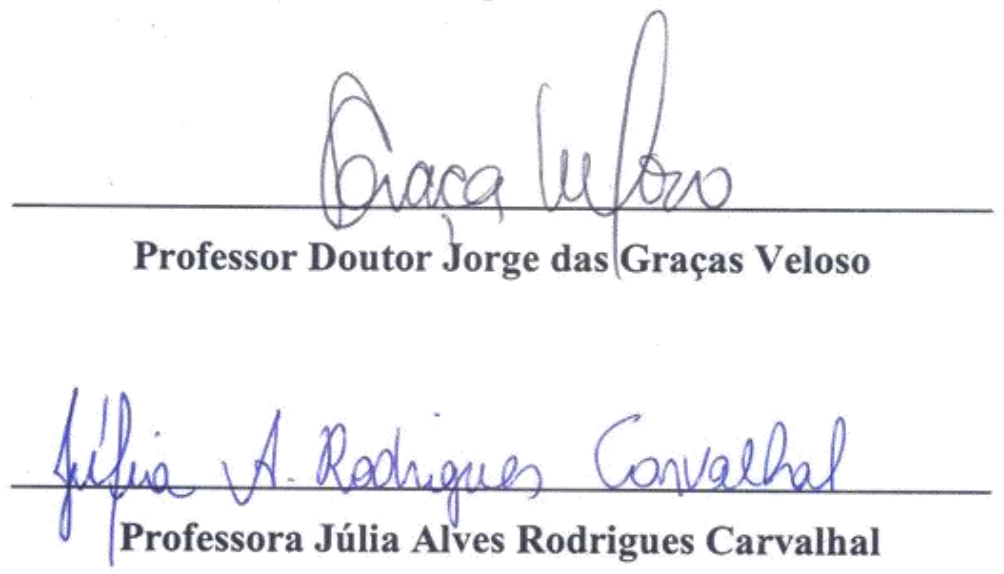
A Deus, que me deu inteligência, criatividade, determinação e proveu tudo que eu precisava para concluir este trabalho! Toda a honra e a glória sejam dadas a Ele, o Senhor da minha vida! 


\section{AGRADECIMENTOS}

A Deus, que meu deu esta oportunidade de realizar um sonho que tinha há muito tempo e, em meio a tantas dificuldades, deu-me forças para chegar ao final e ter esta vitória.

À minha família, que tem me acompanhado desde o começo.

Ao Fabio, que há 13 anos me deu a oportunidade de ter minha primeira experiência teatral, a primeira de muitas e que hoje, com o tempo e a maturidade, tem crescido a cada dia a vontade de me aprofundar ainda mais nos estudos das Artes Cênicas. Obrigada!

Ao querido MTAF, que tanto tenho admiração. Meus queridos, vocês sabem como eu os amo e os estimo. Contem sempre comigo! Obrigada pelo apoio!

A todos da IBBR, que têm acompanhado minha trajetória acadêmica, presenciado minhas dificuldades, mostrando-se sempre amáveis, amigos e torcendo para que eu obtivesse sucesso, e também, a todos os amigos do Seminário que torceram por mim desde o início desta graduação! Muito obrigada!

À querida Irlanda, que despertou em mim o amor pelo ensino. Você deixou uma marca em minha vida querida, obrigada!

À Luciene, que me ajudou com um rico material de pesquisa para que eu conseguisse elaborar este trabalho e também à Ivanilda pelo excelente trabalho de revisão textual. Obrigada queridas!

A todos os colegas da Escola Educação Criativa, que me apoiaram em meus estudos e contribuíram para que este momento ímpar acontecesse em minha vida! Obrigada pelo apoio!

Às três professoras de teatro que se disponibilizaram de forma prestativa para as entrevistas contidas neste trabalho. Obrigada!

Ao orientador Prof. Ms. Tiago de Brito Cruvinel, pela dedicação, paciência e pela forma atenciosa com a qual me ajudou durante todo este trabalho. Além de me auxiliar, mostrou-me, ainda, que eu posso continuar, certa de que a trajetória acadêmica não termina por aqui. Muito obrigada por me encorajar e contribuir para a realização deste sonho!

A todos aqueles que de forma direta ou indireta me ajudaram e torceram por mim, obrigada!

Estou muito feliz por esta realização tão importante em minha vida! Obrigada Deus!!! 


\section{RESUMO}

O presente trabalho reflete sobre as características dos alunos com Déficit de Aprendizagem. O objetivo é verificar se a linguagem teatral contribui no desenvolvimento escolar de alunos com esse déficit. Para entender a realidade dos trabalhos pedagógicos desenvolvidos, foram entrevistadas três professoras de teatro das cidades de Brasília-DF, Sete Lagoas-MG e MarilacMG. A partir dessas entrevistas, traçou-se os perfis dos alunos com esse diagnóstico e buscouse compreender quais são os procedimentos pedagógicos e artísticos trabalhados, por meio da linguagem teatral, que permitem o desenvolvimento e o primoramento de habilidades dos estudantes que superam limitações decorrentes do transtorno.

Palavras-chave: Déficit de Aprendizagem. Linguagem Teatral. Ensino e Aprendizagem. 


\section{SUMÁRIO}

INTRODUÇÃO ........................................................................................................................8

1- O DÉFICIT DE APRENDIZAGEM: COMPLEXIDADES DO ALUNO COM O TRANSTORNO NO AMBIENTE EDUCACIONAL ..............................................................12

2- A LINGUAGEM TEATRAL: ESTRATÉgIAS PEDAGógICAS NO DESENVOLVIMENTO ESCOLAR DE ALUNOS COM DÉFICIT DE APRENDIZAGEM .............................................................................................................. 19

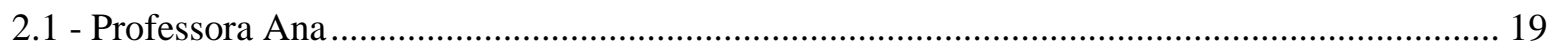

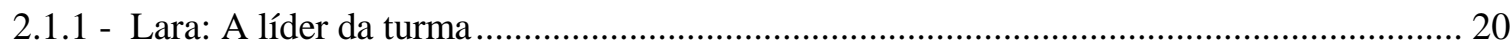

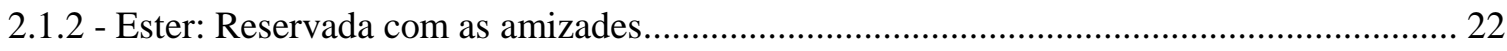

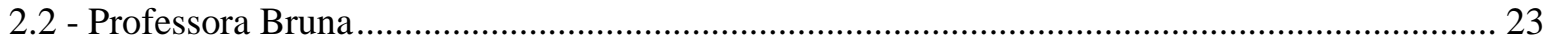

2.2.1 - Vitória: O afeto como estímulo para a aprendizagem........................................................ 24

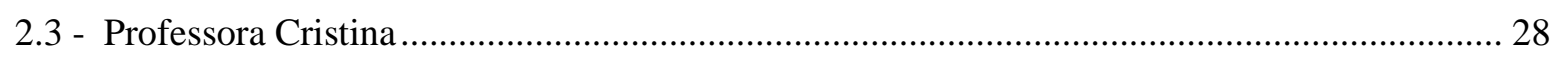

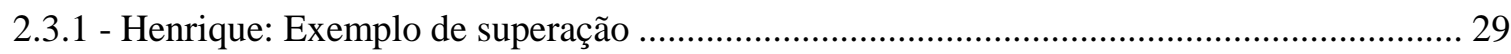

CONSIDERAÇÕES FINAIS................................................................................................34

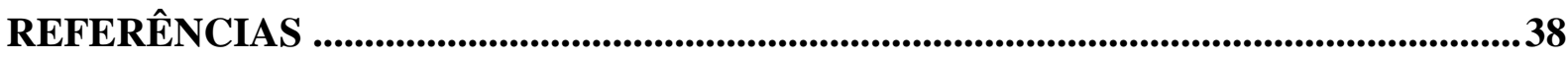




\section{INTRODUÇÃO}

Sou da cidade de Ipatinga, em Minas Gerais, e trabalho há mais de dois anos na secretaria de uma escola particular de minha cidade. Durante esse tempo, tenho percebido que quando os pais conversam com os professores ou com a coordenação sobre o desenvolvimento dos seus filhos, relatando que estão com dificuldade na assimilação do conteúdo, muitos alunos são encaminhados para um psicólogo com o objetivo de avaliar a causa dessa dificuldade.

Ao observar este fato com certa frequência, comecei a refletir sobre o assunto. Dentre os que são encaminhados para esse profissional, alguns alunos apresentam um laudo à escola com o diagnóstico de algum transtorno que tem interferido no processo de aprendizagem. Diante desta problemática, este trabalho visa pesquisar e verificar se a linguagem teatral pode contribuir para que os alunos com Déficit de Aprendizagem tenham melhores rendimentos escolares.

Rubem Alves (2004) diz que "os professores não são aqueles que conhecem os saberes. São aqueles que sabem encontrar caminhos para eles" (p.49). Desta forma, acredito que o professor de teatro, ao lecionar aspectos sobre a linguagem teatral, poderá mostrar um caminho para o estudante que, ao percorrê-lo, terá a possibilidade de encontrar novos saberes que o instigarão no processo de aprendizagem. Percebo também que, por meio do teatro, o sujeito pode se desenvolver em diversas áreas contribuindo para a sua formação humanitária e aprimorar habilidades que podem promover um melhor desenvolvimento escolar. Portanto, o teatro é um recurso pedagógico e artístico muito rico que agrega valores e pode influenciar os alunos com Déficit de Aprendizagem de forma positiva no ambiente escolar.

Para realizar esta pesquisa, foram selecionados autores que contribuem para problematizar o tema desta monografia. SMITH; STRICK (2012) e PAÍN (2003) esclarecem sobre o Déficit de Aprendizagem em relação às características e aos fatores a serem considerados no diagnóstico. TOPCZEWSKI (2000) e VYGOTSKY (1991) irão abordar sobre as definições do transtorno, o desenvolvimento da cognição no processo de aprendizagem e as causas do Déficit de Aprendizagem. Sobre alguns dos elementos presentes na linguagem teatral, serão discutidos por meio de LINO (2012), SCARPATO (2001), VIEIRA (2005), ICLE (2012), PRADOS; MERÍSIO (2009). O teatro como proposta pedagógica e artística no ambiente escolar e o jogo teatral como estratégia didática e metodológica vão ser discutidos por meio de OLIVEIRA; STOLZ (2010) e GAMA (2010). Os elementos formativos da educação e as 
contribuições da Arte na formação do sujeito serão discutidos por meio de BARBOSA (1975) e a LDB (1996). Sobre as possíveis falhas no sistema educacional que prejudicam o processo de aprendizagem, será abordado por FERNÁNDEZ (1991). Em relação às influências positivas da família, escola e professor no que diz respeito ao afeto, essas serão relatadas por ALENCAR; FLEITH (2009), OLIVEIRA, BITTENCOURT, CARMO (2008), ALVES (2004) e MORALES (2006).

Para uma articulação entre teoria e prática, apresentarei também entrevistas com professoras de teatro das cidades de Brasília-DF, Sete Lagoas-MG e Marilac-MG, realizadas na primeira semana de outubro de 2014, que ajudaram a compreender a realidade dos trabalhos pedagógicos desenvolvidos com alunos que apresentam esse transtorno. A partir dessas entrevistas, relatarei como essas professoras têm lidado com os alunos com o Déficit de Aprendizagem e se o teatro tem contribuído no rendimento escolar dos estudantes.

No decorrer deste trabalho, pretendo responder às seguintes perguntas: a linguagem teatral produz melhorias no desempenho do aluno em sua vida escolar? Os professores entrevistados perceberão se a linguagem teatral promoveu ou não, o rendimento escolar e o desenvolvimento pessoal dos alunos? Desta forma, investigarei quais têm sido os resultados obtidos por meio da linguagem teatral em alunos com Déficit de Aprendizagem.

Silva (2012) afirma que “[...] poucas escolas agregam em sua grade curricular a disciplina Pedagogia do Teatro que tem sido uma grande aliada do estudante no seu processo de construção de saberes, podendo auxiliar também na resolução de conflitos psicológicos" (2012, p.14). Infelizmente, percebemos esta realidade bem presente nas escolas. O teatro favorece a educação de forma dinâmica e contribui para que o estudante possa se desenvolver não só como aluno, mas como cidadão.

O ensino da Arte é fundamental para o desenvolvimento mais amplo do aluno. Ela faz com que diversas capacidades intelectuais sejam aprimoradas e outras sejam adquiridas, o que contribui para que o estudante tenha sua formação não somente na instituição de ensino, mas também da sua subjetividade.

A escola é o ambiente onde se deve promover o despertar de novos saberes e motivar o aluno a se superar em suas dificuldades por meio de estratégias pedagógicas. Mas, por vezes, percebemos que, se o aluno tem baixas notas e não corresponde às expectativas da escola, ele 
é rotulado como um aluno fraco e suas qualidades e progressos não são tão valorizados como deveria.

É comum dar destaque à incapacidade, à ignorância e à incompetência do aluno, deixando de assinalar o que cada um tem de melhor em termos de talento e habilidades. Isso leva ao desenvolvimento de uma visão pessimista dos próprios recursos intelectuais, da capacidade de criar, de propor novas ideias e de vislumbrar novas possibilidades e opções diante de problemas e desafios. (ALENCAR e FLEITH, 2009, p.134)

Como vemos, na citação acima têm-se a tendência de reforçar negativamente as dificuldades e não estimular o que o aluno tem de potencial. O aluno com Déficit de Aprendizagem tem capacidades que devem ser trabalhadas de forma que o motive a superar suas dificuldades.

Ken Robinson, educador inglês (2010), afirma que:

A educação é o sistema que supostamente deveria desenvolver nossas aptidões naturais e nos permitir trilhar nosso caminho no mundo. Em vez disso, ela está sufocando os talentos e habilidades de um número excessivo de estudantes e acabando com a motivação deles para aprender. (2010, p. 28)

Podemos perceber que o lugar que seria mais apropriado para que os alunos pudessem ser instigados a descobrir seus talentos e aptidões, muitas vezes, é o mesmo que reprime o aprendizado. O sistema educacional, por vezes, engessa o aluno em relação às suas habilidades privando-o de aprender de uma forma diferenciada do que a educação formal tem oferecido ao longo dos anos.

Acredito que a vivência com a linguagem teatral poderá contribuir para que os alunos que apresentam dificuldade na aprendizagem possam se desenvolver e consigam melhorar sua capacidade de assimilação dos conteúdos escolares. Deste modo, pretendo focalizar minhas análises sobre os alunos com Déficit de Aprendizagem e relacioná-las com as entrevistas das professoras de teatro que trabalham com alunos que tenham este perfil. Por esse motivo, as entrevistas com as docentes serão um instrumento importante de análise, pois mostrarão como tem sido o contato da linguagem teatral com os alunos que apresentam o Déficit de Aprendizagem. Desta forma, as entrevistas têm o intuito de verificar se os alunos tiveram avanços no processo de aprendizagem mesmo diante de suas limitações, trazendo uma compreensão mais ampla sobre a Arte-Educação nas escolas.

O aprendizado do aluno com esse transtorno pode ser um pouco mais lento do que para os alunos que não possuem esta deficiência, porém, ele tem capacidade de assimilação e é um ser capaz de desenvolver seu aprendizado. Oliveira e Stoltz (2010) ressaltam que "Vygotsky 
diz que não se impõe nada, que não é possível mudar o outro, mas é a própria pessoa que modifica suas reações pela experiência com os objetos do mundo" (p.80), ou seja, através da experiência, a pessoa pode superar suas dificuldades, mesmo que elas façam parte da pessoa desde o seu nascimento. Todos nós temos a predisposição para o processo de aprendizagem independentemente de fatores físicos ou genéticos. O aluno pode ter dificuldade para aprender, mas isso não impede que ele aprenda.

Inicialmente, no primeiro capítulo, abordarei questões sobre o aluno com o Déficit de Aprendizagem, tais como: características, causas, consequências, diagnóstico, o papel da família, incentivos na aprendizagem e contribuições da Arte no desenvolvimento escolar.

No segundo capítulo, relatarei sobre o perfil dos alunos e a influência dos processos pedagógicos e artísticos no ensino da linguagem teatral no ambiente escolar de forma que potencialize o processo de aprendizagem dos alunos.

Ao final deste trabalho, comentarei sobre as conclusões obtidas a partir dos relatos das entrevistas com as professoras que utilizam a linguagem teatral como estratégia pedagógica para auxiliar no desenvolvimento dos alunos com Déficit de Aprendizagem. 


\section{1- O DÉFICIT DE APRENDIZAGEM: COMPLEXIDADES DO ALUNO COM O TRANSTORNO NO AMBIENTE EDUCACIONAL}

Estamos em constante processo de aprendizagem. Tudo à nossa volta são estímulos para que assimilemos as mais variadas informações, internalizadas através dos nossos cinco sentidos sensoriais: visão, audição, tato, olfato e paladar, e, em cada percepção, é registrada uma aprendizagem diferente em nossa memória.

TOPCZEWSKI (2000), neurologista da infância e adolescência, indaga e nos traz uma definição sobre a aprendizagem:

O que é aprendizagem? É a capacidade e a possibilidade que as pessoas têm para perceber, conhecer, compreender e reter na memória as informações obtidas. É este o cortejo que leva à ampliação e ao enriquecimento das experiências anteriormente vividas; trata-se de um processo complexo que possibilita a criação e o desenvolvimento de novos conhecimentos. É por meio do aprendizado que se modifica o comportamento intelectual e social dos indivíduos. Portanto, o aprendizado é um processo fundamental na vida do ser humano (2000, p.17).

Desta forma, podemos perceber que a memória é a responsável pela aquisição e registro de tudo que assimilamos. Ela faz parte do sistema cognitivo e registra todos os elementos que conseguimos perceber através dos cinco sentidos, citados acima. Vygotsky (1991) relata que "a memória, em fases bem iniciais da infância, é uma das funções psicológicas centrais, em torno da qual se constroem todas as outras funções” (p.36), ou seja, tudo que assimilamos fica registrado em nossa memória, contribuindo para que outras funções cognitivas sejam desenvolvidas.

Sobre o aprendizado, Vygotsky relata ainda que:

O aprendizado é mais do que a aquisição de capacidade para pensar; é a aquisição de muitas capacidades especializadas para pensar sobre várias coisas. O aprendizado não altera nossa capacidade global de focalizar a atenção; ao invés disso, no entanto, desenvolve várias capacidades de focalizar a atenção sobre várias coisas (1991, p.55-56).

$\mathrm{O}$ ato de aprender desencadeia diversas outras funções em nossa mente, o que contribui para que venhamos descobrir e adquirir saberes que não tínhamos conhecimento. Ao descobrilos, percebemos, também, que instigamos a habilidade de nos concentrarmos em outras informações.

Todas as informações que processamos vão contribuir para a formação da nossa subjetividade e, quando pensamos na formação do sujeito, que pode vir a desempenhar um 
papel relevante na sociedade, percebemos que a educação é fundamental para que essa formação aconteça de forma ampla.

No artigo $1^{\text {o }}$ da LDB - Lei de Diretrizes e Bases, $n^{\circ} 9.394$ de 1996, vemos o que compreende a educação:

A educação abrange os processos formativos que se desenvolvem na vida familiar, na convivência humana, no trabalho, nas instituições de ensino e pesquisa, nos movimentos sociais e organizações da sociedade civil e nas manifestações culturais (LDB - Lei n ${ }^{\circ}$ 9.394/96, BRASIL, 1996, p.1).

Desta forma, percebemos que a família também desempenha um papel extremamente relevante na formação. É com ela que a criança aprende os primeiros passos, as primeiras palavras, assim ela vai adquirindo sua visão de mundo e aprendendo diversas coisas. A escola também desempenha o papel fundamental em nossa trajetória educacional. Somos seres pensantes que conseguem formar uma opinião ou ter determinada atitude mediante aquilo que aprendemos, e a escola tem função fundamental na formação de cidadãos na sociedade.

$\mathrm{Na}$ escola, somos estimulados a realizar diversas tarefas que irão favorecer nossa formação intelectual. Diante de nós, são colocados desafios que irão contribuir para que nos superemos diariamente no processo de aprendizagem. Em meio a estes desafios, podem surgir dificuldades de compreensão sobre o que é ministrado, e é natural que elas aconteçam. O fator determinante é perceber como lidarmos com estas dificuldades e se temos o suporte necessário da escola para que consigamos superá-las.

Mas e quando não conseguimos? E se a escola não tiver o suporte necessário que contribua para o avanço educacional? E se o professor não tem o devido preparo para instigar o aluno a ir além no processo? O problema está no aluno, na instituição, no professor ou na família? São questionamentos que devemos fazer para que consigamos detectar a raiz do problema. Dentre estes e outros questionamentos, este trabalho visa discutir sobre o Déficit de Aprendizagem e refletir sobre a gama de elementos que giram em torno desta problemática no ambiente educacional.

O aluno diagnosticado com Déficit de Aprendizagem apresenta, a princípio, baixo rendimento escolar, tanto em relação às notas quanto ao seu comportamento em sala de aula. Smith, professora especialista em dificuldades de aprendizagem e Strick, especialista em dificuldades de aprendizagem, relatam que:

O que as crianças com dificuldades de aprendizagem têm em comum é o baixo desempenho inesperado. Na maior parte do tempo, elas funcionam de um 
modo consistente com o que seria esperado de sua capacidade intelectual e de sua bagagem familiar e educacional, mas dê-lhes certos tipos de tarefas e seus cérebros parecem "congelar" (2001, p.15).

Podemos perceber que, a princípio, o aluno não apresenta qualquer dificuldade no ambiente escolar. A incapacidade de conseguir realizar alguma tarefa por achá-la difícil pode ser porque o aluno ainda não tem familiaridade com o conteúdo e por isso precise estudar um pouco mais para que obtenha a assimilação.

Dessa forma, o aluno acaba tendo um rendimento escolar baixo devido às suas limitações com determinadas matérias, não correspondendo às expectativas. Mas será que o "branco" na hora de fazer alguma prova ou atividade é motivo para dizer que ele é um aluno fraco? Será que o método utilizado para ensinar a matéria foi o mais adequado? Será que a didática em sala de aula foi satisfatória? São questionamentos que devemos nos fazer para que possamos compreender o problema.

Ao pensarmos no baixo rendimento escolar devido à dificuldade de aprendizagem, Topczewski nos apresenta as causas do transtorno:

Várias são as causas relacionadas às dificuldades na aprendizagem escolar, como, por exemplo: comprometimento do nível intelectual, alterações comportamentais, distúrbios emocionais, inadequação pedagógica, inadaptação ao método de ensino, inadequação familiar, dificuldades específicas do aprendizado, doenças orgânicas agudas e crônicas e disfunções do sistema nervoso central (2000, p.23).

Podemos perceber que são várias as causas que podem desencadear esse transtorno. Ele acontece não só devido a uma falha orgânica, mas também, a uma falha ambiental, no que diz respeito à escola e à família.

Para Paín (2003), psicóloga e doutora em filosofia, "os fatores fundamentais que precisam ser levados em consideração no diagnóstico de um problema de aprendizagem são os seguintes: fatores orgânicos [...], específicos [...], psicógenos [...] e ambientais [...]" (2003, p.2833). Destes quatro, o fator ambiental é essencial para o diagnóstico. "O fator ambiental é especialmente determinante no diagnóstico do problema de aprendizagem, na medida em que nos permite compreender sua coincidência com a ideologia e os valores vigentes no grupo" (2003, p.33). O fator ambiental é o que mais aparece em problemas escolares e, geralmente, os professores são os primeiros a perceberem que o aluno tem certa dificuldade de assimilação.

Em alguns laudos lidos antes da pesquisa, observei que o profissional orientava que o aluno se sentasse na primeira cadeira, de frente para o professor e, em alguns casos, quando o 
estudante tinha dificuldade de se concentrar, fazia a avalição em uma sala separada. Nota-se, com isso, que a escola atende as orientações do profissional, mas foi possível perceber que muitas vezes são reforçadas, de forma negativa, as dificuldades do aluno e não é reforçado, de forma positiva, o que ele tem a oferecer ou a desenvolver. Esses alunos são tidos como fracos devido à sua dificuldade. Este é um fator que para mim traz muito incômodo, pois, no meio pedagógico, os alunos que não têm um rendimento escolar esperado, de acordo com a proposta pedagógica da escola, são rotulados e vistos de forma diferente. Smith e Strick (2001) ressaltam que "a verdade é que muitos alunos fracos são vítimas da incapacidade de suas escolas para ajustarem-se às diferenças individuais e culturais" (p. 34).

O aluno pode ter tendência a desencadear um comportamento desviante devido ao seu diagnóstico ocasionado até mesmo por uma possível baixa autoestima. Smith e Strick (2001) relatam que "estudos mostram que adolescentes com dificuldades de aprendizagem não apenas estão mais propensos a abandonar os estudos, mas também apresentam maior risco para abuso de substâncias, atividade criminosa e até mesmo suicídio" (p.16).

Geralmente, temos a tendência de julgar a escola pública como fraca no sentido de não proporcionar uma estrutura mais consistente à educação e colocamos a escola particular em uma posição superior. Não podemos negar que a instituição privada possa ter uma estrutura educacional mais ampla no que diz respeito ao ensino, à qualificação de professores, ao investimento de melhores condições físicas e de um acompanhamento minucioso em relação ao desenvolvimento do aluno, dentre outros, mas também não podemos "rotular" a escola pública.

Com toda essa estrutura, poderíamos pensar que os alunos, teoricamente, têm todas as condições favoráveis para uma aprendizagem de qualidade em relação à escola pública. No entanto, o que tenho percebido é que, normalmente, os alunos que mais são diagnosticados com algum transtorno da aprendizagem estão na instituição privada. Fernández (1991), psicopedagoga, afirma que "muitas crianças não demostram sintomas na aprendizagem, imersos em um sistema educativo deplorável, enquanto outros sintomatizam gravemente seu aprender, dentro de sistemas educativos muito bons" (p.84).

Diante disso, podemos nos perguntar: Por que são feitos tantos encaminhamentos dos alunos para os profissionais da saúde mental? Será que é por que os alunos não estão correspondendo aos resultados esperados pela escola? Será que estão sendo cobrados além do que podem dar conta? Por eles terem certas dificuldades em alguma matéria e não tirarem notas 
boas, eles podem ter algum Déficit de Aprendizagem? São questionamentos que podemos levantar, porque muitas vezes o que ocorre é que se criam expectativas elevadas no aluno em relação ao seu rendimento escolar, principalmente, em relação às notas, dando destaque às suas dificuldades e não aos seus progressos.

Este trabalho não tem a pretensão de julgar os posicionamentos da escola diante da situação e nem de questionar o diagnóstico dado pelo profissional sobre o aluno, mas visa levantar reflexões, de forma que possamos repensar as questões que giram em torno desta problemática em relação às possibilidades de o aluno desenvolver seu potencial, amenizando, de certa forma, sua dificuldade. Além disso, objetiva mostrar a percepção do professor de teatro sobre os possíveis avanços deste aluno ao ter o contato com a linguagem teatral e o que ela pode favorecer para os alunos nesta condição.

Quero destacar nesta pesquisa, também, a grande relevância da participação familiar na educação. Smith e Strick, afirmam que:

O ambiente doméstico exerce um importante papel para determinar se qualquer criança aprende bem ou mal. Um imenso conjunto de pesquisas tem demonstrado que um ambiente estimulante e encorajador em casa produz estudantes adaptáveis e muito dispostos a aprender, mesmo entre crianças cuja saúde ou inteligência foi comprometida de alguma maneira (2001, p.31).

Deste modo, percebemos que o fator familiar pode instigar, ou não, a influência da aprendizagem. Os pais devem proporcionar um ambiente favorável e estimulante aos filhos de forma que contribuam na educação e possam diariamente superarem suas dificuldades. As autoras reforçam sobre a ação motivadora dos pais:

Além disso, as crianças que recebem um incentivo carinhoso durante toda a vida tendem a ter atitudes positivas, tanto sobre a aprendizagem quanto sobre si mesmas. Seu espírito de "Eu posso fazer isso" as ajuda a enfrentarem os desafios e a superarem os obstáculos. Essas crianças buscam ou encontram modos de contornar as deficiências, mesmo quando são bastante graves. "É fácil reconhecer as crianças que realmente têm famílias envolvidas e incentivadoras", diz uma professora de educação especial. Embora tenham dificuldades de aprendizagem, elas veem a si mesmas como basicamente competentes e bem-sucedidas (Ibdem, 2001, p.31).

Podemos perceber que o afeto no lar proporciona um apoio seguro para o aluno e o faz sentir-se mais confiante, mesmo em meio às suas dificuldades. É um trabalho em equipe, no qual todos ganham.

Quando pensamos em um jogo, além dos próprios jogadores, vemos a forte presença do treinador e da torcida. Percebemos que em muitas famílias existem apenas os pais que torcem 
pelo sucesso de seus filhos. Mas ser torcedor não é o suficiente na jornada da vida. Por vezes, é preciso que os pais exerçam o papel de treinador de seus filhos. Advertir quando necessário, instruir, indicar o caminho. Realizando as devidas correções, o filho vai aprender a lidar com suas dificuldades, encarando-as de frente e buscando sempre se superar.

Ressalta-se que os pais devem ter equilíbrio nessas duas funções. A família deve estar unida no mesmo propósito de investir e motivar seus filhos a irem mais além em todas as áreas da vida, em especial, na educação.

Em relação à educação no ambiente formal, o professor exerce uma função extremamente importante, pois é ele quem vai contribuir para que o aluno possa desenvolver suas habilidades.

O respeito pelo aluno e por suas ideias, o incentivo à reflexão e à participação dos alunos, além da promoção no aluno da motivação, da persistência e da autoconfiança foram alguns aspectos salientados [...] no professor propiciador do desenvolvimento das habilidades criativas (ALENCAR e FLEITH, 2009, p.150).

Percebemos que o professor que motiva seus alunos em relação às suas ideias contribui para que os estudantes desenvolvam sua criatividade, fomentando seu potencial. Em cada um de nós existe um potencial adormecido, que muitas vezes não são estimulados a se despertar para uma vida que pode ser recheada de conquistas e superações, apesar das limitações.

Quando pensamos nos fatores que contribuem para o processo de aprendizagem, percebemos também a forte influência da Arte, pois ela desperta e aguça a sensibilidade no sujeito que, no ato de criar, ou mesmo, de realizar alguma atividade artística, coloca suas emoções nesse processo.

[...] sabemos que, pelos processos afetivos que mobiliza, a Arte pode ser um poderoso auxiliar para o enriquecimento do processo de aprendizagem dos demais conteúdos cognitivos escolares, e são firmemente aceitos os objetivos relacionados com a ênfase dessa função da Arte-educação (BARBOSA, 1975, p.90).

Diante disso, percebemos que a Arte pode contribuir de forma relevante até mesmo no processo de ensino e aprendizagem de matérias regulares no currículo escolar, sendo uma poderosa ferramenta ao professor, que deve se apropriar dela para que seus alunos tenham uma maior compreensão sobre o conteúdo, como relata Barbosa (1975) dizendo que "a Arte é a disciplina do currículo que atinge o desenvolvimento do educando numa maior variedade de dimensões" (1975, p.106).

A Arte dialoga com ela mesma e com outras ciências e, no processo de aprendizagem, agrega valores e saberes, contribuindo para a formação do aluno não somente no ambiente 
escolar, mas em sua vida fora da escola também. Um sujeito formado mais consciente de suas habilidades é um cidadão que pode contribuir na sociedade que está inserido.

Ao longo deste capítulo, levantei questões sobre as causas do Déficit de Aprendizagem, no que diz respeito aos fatores ambientais em relação à escola, à família e às possíveis falhas que podem desencadear este transtorno no aluno. Foram relatados, também, fatores que podem contribuir com a aprendizagem, as grandes contribuições de uma família incentivadora na formação do aluno como sujeito e a Arte como linguagem instigadora e poderosa no processo de ensino e aprendizagem.

No próximo capítulo, abordarei como a linguagem teatral pode ser um instrumento pedagógico e um grande aliado na educação. 


\section{2- A LINGUAGEM TEATRAL: ESTRATÉgIAS PEDAGÓGICAS NO DESENVOLVIMENTO ESCOLAR DE ALUNOS COM DÉFICIT DE APRENDIZAGEM}

Este capítulo aborda a influência da linguagem teatral como estratégia para contribuir no desenvolvimento escolar de alunos com Déficit de Aprendizagem.

Lino (2012), licenciada em Teatro, descreve sobre a linguagem teatral. Para ela, os princípios dessa linguagem são:

a atuação, ou a realização pelo ator de ações para desenvolver um percurso; a encenação, ou a organização das ações dos atores, dos espaços e de suas características para a fruição do espectador; e a recepção, ou a relação com o espectador (p.28).

Deste modo, podemos perceber que a linguagem teatral é um recurso pedagógico extremamente relevante para o desenvolvimento escolar, pois os estudantes trabalham diversos aspectos artísticos que promovem a consciência corporal, a sociabilização e a ampliação dos processos criativos.

Para realização da pesquisa, foram entrevistadas ${ }^{1}$ três professoras de teatro das cidades de Brasília-DF, Sete Lagoas-MG e Marilac-MG que trabalham com alunos com este transtorno. Relatarei o perfil dos alunos descritos pelas professoras. É importante ressaltar que, em algumas situações, não foi possível ter informações mais detalhadas, pois, na entrevista, em alguns momentos, as professoras explicavam sobre os alunos considerando a turma como um todo. Por esse motivo, em determinados casos, abordarei de uma forma mais ampla as impressões das professoras sobre os alunos com Déficit de Aprendizagem.

\section{1 - Professora Ana}

Ana é professora de teatro e trabalhou em uma escola particular, em Sete Lagoas-MG, por 2 anos, nas séries iniciais do Ensino Fundamental. Dentre os estudantes, ela tinha duas alunas com Déficit de Aprendizagem. Relatarei sobre cada uma, individualmente.

\footnotetext{
${ }^{1}$ As entrevistas foram gravadas nos dias 2 e 4 de outubro de 2014 com a autorização por meio do Termo de Consentimento Livre e Esclarecido. Os nomes citados são fictícios para preservar a identidade das professoras e dos alunos.
} 


\subsection{1 - Lara: A líder da turma}

Lara tem 9 anos, está no $4^{\circ}$ ano do Ensino Fundamental e foi diagnosticada no ano anterior, quando estava no $3^{\circ}$ ano. Além de Déficit de Aprendizagem, ela possui o diagnóstico de $\mathrm{TDAH}^{2}$ e é medicada com Ritalina ${ }^{3}$. Segundo relatos da professora Ana, quando a aluna não tomava a medicação, ficava hiperativa, transtornada, sentia-se perseguida pelos colegas e chorava. No teatro, ela tinha um ótimo rendimento. Nas disciplinas regulares, ela era uma aluna que gostava de sair da cadeira, andar, falar com os colegas, perguntar, questionar. As outras professoras relatavam no conselho de classe que ela havia melhorado com a medicação. A professora Ana entende que elas relatavam isso, porque a aluna não ficava mais agitada na sala e permanecia quieta, mas não em relação à assimilação do conteúdo pela aluna. A psicóloga do colégio acompanhava o caso. A professora acredita que ela começou a tomar a medicação um ano antes de lecionar para ela. Os pais são separados e ela tem uma irmã que sempre está doente. Ano passado, ela morou com o pai e este ano voltou a morar com a mãe. É uma criança que dorme muito tarde, acorda muito cedo e não tem uma supervisão dos pais sobre esta situação. A mãe é super presente, mas trabalha muito e cuida de 2 filhas (Lara e a irmã). A professora percebe que, apesar de ter TDAH e Déficit de Aprendizagem, ela é uma líder, pois é muito sociável e todas as colegas querem segui-la. Ela diz que a relação familiar, talvez, possa ter contribuído para que a aluna fosse diagnosticada com o Déficit de Aprendizagem.

A professora Ana relatou que ano passado ela trabalhou com teatro de sombras com os alunos do $4^{\circ}$ ano. No momento da apresentação, quando os alunos tinham que colocar em cena a sua sombra, a professora percebia que Lara estava sempre distraída mexendo com outra coisa, e não notava o que estava acontecendo ao seu redor. A professora tinha que orientá-la para prestar mais atenção na atividade de forma que a sua participação fosse mais ativa. Este fato mostra de forma clara o comportamento dessa aluna com o transtorno durante a atividade e as dificuldades que a professora enfrentava com a sua distração.

O teatro de sombras é um gênero teatral que faz parte do teatro de formas animadas ou teatro de animação. De acordo com Lino (2012), o teatro de sombras "consiste em manipular figuras em foco de luz projetadas nas sombras em uma tela. As figuras de sombra, são chamadas de silhuetas ou bonecos de sombra, podem ser silhuetas chapadas ou tridimensionais, articuláveis, ou não" (p.21). A sombra entra em cena que é manipulada pelo ator.

\footnotetext{
2 Transtorno de Déficit de Atenção e Hiperatividade.

${ }^{3}$ Medicamento indicado para o tratamento de TDAH.
} 
Esta atividade desenvolve a criatividade e a coordenação motora, ao realizar a confecção da silhueta da sombra e do cenário. Na apresentação da cena, desenvolve também a atenção e a concentração tanto nas entradas quanto na interação com as demais sombras e atoresmanipuladores.

Por esse motivo, acredito que o aluno com Déficit de Aprendizagem é motivado a desenvolver essas habilidades, devido ao próprio objetivo da atividade. Mesmo que ela seja realizada com a turma de uma forma geral, observo que o aluno com o transtorno desenvolve aspectos cognitivos através desta atividade, apesar das suas limitações.

O papel do professor é de um instigador para que o aluno possa vencer barreiras e superar suas dificuldades por meio dos aspectos pedagógicos e artísticos que ele propõe aos alunos através das atividades.

A professora Ana contou ainda que desenvolveu um trabalho de dança-teatro e performance com os alunos do $4^{\circ}$ ano. Segundo ela, os alunos nesta faixa etária, por serem muito agitados, não conseguem permanecer focados por muito tempo em uma atividade mais teórica ou muito parada. Ela utilizou esse recurso artístico para que os alunos pudessem desenvolver a criação livre através da dança.

Segundo Scarpato (2001), mestra em Educação Física, pedagoga e professora de Dança Educativa, "a escola precisa realizar experiências com o corpo dos alunos, que não é um esqueleto a ser treinado pela repetição de movimentos, mas por atividades prazerosas" (p.61), e a dança é uma dessas atividades que além de ser prazerosa, promove consciência corporal, memória, coordenação motora, noção espacial e a sociabilização.

Sobre a dança-teatro, Vieira (2005), mestre em educação, especialista em pedagogia do movimento e graduado em Artes cênicas, diz que

Não pensamos na dança e no teatro em separado, mas pensamos na junção e trocas mútuas entre essas duas linguagens que, configuradas numa hibridação, mostram-se hoje na Dança-teatro. Essa hibridação vai acontecer quando dança e teatro dialogam como linguagem única (p.113).

Nesta junção entre a dança com o teatro, temos um recurso pedagógico que desenvolve muito a questão corporal. Nele há os aspectos da dramatização com a dança que se unificam em uma só linguagem. No corpo, são produzidos e projetados todos movimentos e os sentimentos de forma ritmada. Com isso, o aluno tem sua percepção corporal mais expandida e aprimorada. 
Gilberto Icle (2010), Doutor e professor da UFRGS, relata sobre as relações que podem ser aplicadas à performance na educação:

[...] Estudos da Performance oferecem uma rica gama de possibilidades na qual a Performance e a Performatividade aparecem como instrumentos pelos quais é possível pensar as relações sociais, as políticas públicas, as identidades de gênero e de raça, a estética, a infância, os rituais, a vida cotidiana, entre outras (p.15).

Podemos perceber a gama de elementos que podem ser representados por meio da performance. São os mais variados assuntos que, através da apresentação performática na escola, os alunos podem aprender e se manifestar nas atividades. $\mathrm{O}$ autor não fecha a lista sobre as áreas a serem trabalhadas com os alunos na escola. Por meio da performance, os alunos desenvolvem principalmente a criatividade ao pensar de forma crítica para elaborar a sua performance. Dependendo da criação performática, os estudantes desenvolvem também o trabalho corporal, a concentração, dentre outros.

\subsection{2 - Ester: Reservada com as amizades}

Ester tem 10 anos, está no $5^{\circ}$ ano e foi diagnosticada quando estava no $4^{\circ}$ ano. Possui o laudo de Déficit de Aprendizagem e também é medicada com Ritalina. A professora Ana disse que as professoras de História e Matemática foram percebendo as dificuldades da aluna devido às notas baixas e ao rendimento ruim. Em grupo, era sociável, desenvolvia-se nas atividades e era criativa. No teatro, era uma boa aluna, mas devido à medicação, a professora percebia que, às vezes, o seu rendimento era prejudicado. A psicóloga do colégio acompanhava o caso. A professora acha que, no caso dela, o Déficit foi causado devido a problemas neurológicos. Os pais são médicos e aparentam ser uma família estruturada. A professora Ana relata que Ester é muito inteligente e sempre quis fazer as aulas de teatro. Em relação às amizades, ela é mais reservada e não tem a mesma sociabilidade com a turma como Lara. Mas de forma geral, Ester se relaciona bem com todos. A professora não sabe dizer se o teatro possibilitou alguma melhoria, porque ela foi diagnosticada recentemente, por isso, ela não conseguiu identificar se realmente melhorou o desempenho da aluna com as aulas de teatro. O pouco tempo de contato da professora com a aluna, depois do diagnóstico, dificultou sua percepção sobre as possíveis melhoras de Ester por meio das aulas de teatro.

A professora Ana relata que, para o $5^{\circ}$ ano, o conteúdo lecionado foi o melodrama. Prados, graduada em Teatro na UFU e Merísio, Doutor e professor na UNIRIO (2009), explicam como é composto o melodrama: 
$\mathrm{Na}$ estrutura melodramática, os personagens tornam-se o centro das tramas, eles são bem delineados e raramente mudam de caráter. São tipos simples e bem definidos. Este tipo de personificação se faz presente em todas as peças do gênero. Por exemplo, a mocinha do melodrama é sempre humilde, ingênua e amorosa, já o vilão se apresenta como gênio mal, invejoso e ambicioso. [...] A certa altura surge no melodrama o personagem cômico, tornando-se uma presença indispensável para quebrar o clima pesado de tensão, depois de uma cena patética e sofrida (p.2).

Percebo que este trabalho desenvolve muito o fazer-teatral, a interpretação, tal como leitura, compreensão de texto, atenção, concentração, memorização, aspectos específicos da cena como posicionamento, entradas e saídas, presença cênica e a própria desenvoltura da atuação. Estes aspectos pedagógicos, na realização deste conteúdo, contribuem para o desenvolvimento do aluno. Mesmo os alunos tendo dificuldade em aprender, essas e muitas outras habilidades podem ser aprimoradas, contribuindo para seu desenvolvimento.

A professora Ana relatou ainda sobre a importância do ensino do teatro com o conteúdo de outras disciplinas:

Eu procurava desenvolver também, um trabalho interdisciplinar. Trabalhamos com o conteúdo de História (com o de teatro) e fizemos um Sarau Imperial. Cada um tinha um personagem para criar, mas um personagem histórico, como a Princesa Isabel, por exemplo. [...] Nessa interdisciplinaridade, a professora notou que eles aprenderam muito mais do que só assistindo aos vídeos ou só lendo os livros didáticos. Essa interdisciplinaridade também proporciona o desenvolvimento cognitivo dos alunos, com certeza.

Percebemos que o teatro é um grande aliado no processo de ensino e aprendizagem juntamente com as demais disciplinas. O dinamismo que o teatro proporciona desenvolve nos alunos um interesse pela matéria que, consequentemente, reflete no seu aprendizado.

O teatro também contribui para que os alunos consigam se expressar melhor. A professora Ana declara que os professores dos conteúdos regulares notaram um crescimento dos alunos mais tímidos em relação à exposição, pois conseguiam falar em público. Dessa forma, percebemos que os alunos conseguiram superar suas limitações devido aos benefícios que o teatro proporcionou para eles.

\section{2 - Professora Bruna}

Bruna é professora de teatro em uma escola particular em Brasília-DF e leciona há 2 anos para o ensino fundamental das séries iniciais e finais. Ela tem 10 alunos com Déficit de Aprendizagem, sendo 1 menina e 9 meninos entre 11 a 14 anos. Estes são acompanhados pela psicopedagoga da escola e fazem tratamento com um psicólogo. Relatarei sobre alguns casos específicos que a professora descreveu. 
Dentre esses alunos, a professora conta que um deles é adotado por uma senhora e teve uma vida muito conturbada; enquanto o outro mora com os pais e, além do transtorno, tem outro laudo de deficiência mental. Esses 2 alunos foram diagnosticados quando tinham 5 anos e hoje eles têm 12 anos de idade. Outro aluno tem algum problema no sistema nervoso e, às vezes, tem convulsões, o que desencadeou o transtorno. Um outro aluno foi diagnosticado este ano, é muito tímido, mas sempre quis fazer as aulas de teatro. Ela não vê diferença com o uso da medicação com estes alunos, pois, apesar de terem o mesmo laudo, ela percebe um comportamento muito diferente entre eles. De acordo com a professora, alguns são inteligentes e tiram notas muito boas, outros têm bastante dificuldade no conteúdo, na realização das tarefas e na organização.

\subsection{1 - Vitória: O afeto como estímulo para a aprendizagem}

Vitória está no $5^{\circ}$ ano. A professora conta que ela sempre fazia alguma brincadeira para atrair a atenção das pessoas e, com isso, atrapalhava as aulas de teatro, porque distraía os outros alunos. A professora Bruna, ao relatar esta situação no conselho de classe, percebeu que as outras professoras estranharam essa observação, porque nas demais aulas ela era uma aluna comportada. Apesar dessa situação, a professora achava que esse comportamento era característico da criança, mas depois de Vitória ser diagnosticada, a professora ficou intrigada com o laudo, pois ela imaginava que essas atitudes eram devido à idade. Com o tempo, a professora começou a ter outra percepção sobre esse comportamento da aluna nas aulas de teatro e relata:

Eu acho que ela se sente tão à vontade comigo que acha que pode ficar tranquila e ser ela mesma na sala de aula, o que eu acho que ela não sente com as outras professoras. Eu acho que ela vê que tem uma separação muito grande entre aluno-professor nas outras disciplinas e, comigo, vejo que ela não sente isso, porque, com a nossa convivência, acredito que ela sente que eu sou sua amiga. Eu acho que é por isso que ela tem um comportamento mais livre nas minhas aulas.

A professora Bruna pensa que nas outras disciplinas a aluna aparenta sentir um distanciamento em relação às professoras de matérias regulares. Mas, nas aulas de teatro, ela não percebe tanto este afastamento, pois, além de ter um bom relacionamento com a professora, Vitória consegue ser ela mesma e se sentir muito à vontade nas aulas. A professora a considera inteligente, criativa, mas, às vezes, fica perdida por causa da medicação, além disso, a educadora não sabe dizer se o teatro possibilitou melhorias para essa criança. 
Diante disso, apesar de a professora não identificar a melhora da aluna, percebe-se que a situação é relevante no desenvolvimento de Vitória, pois, se a aluna consegue ser ela mesma nas aulas, mostra que o teatro a está ajudando no processo de ensino e aprendizagem. $O$ fato de a aluna gostar da professora e das aulas de teatro indica que ela se sente motivada com as atividades, e isso contribui para que a aprendizagem aconteça.

Alves (2004), educador, escritor, psicanalista, Doutor em Filosofia e professor emérito da UNICAMP diz que "toda experiência de aprendizagem se inicia com uma experiência afetiva" (p.20). O professor passa um bom tempo em contato com o aluno vivenciando diversas situações no dia a dia escolar. Se o professor consegue cativar seus alunos, eles terão uma predisposição para aprender o conteúdo ensinado.

Quando se admira um mestre, o coração dá ordens à inteligência para aprender as coisas que o mestre sabe. Saber o que ele sabe passa a ser uma forma de estar com ele. Aprendo porque amo, aprendo porque admiro (ALVES, 2004, p.35).

Em alguma época da nossa vida, tivemos mestres que ensinaram não somente o que estava descrito no planejamento, mas ensinaram com o coração. Mestres que até hoje temos na memória por ter nos causado uma influência e um impacto positivo em nossa vida estudantil. Mesmo não tendo certa facilidade para entender o conteúdo da matéria, através do relacionamento do professor com a classe, algumas barreiras eram quebradas e tínhamos um interesse em aprender a disciplina.

Todos os professores podem ser modelo de identificação; porém, quando se trata de prestígio e, além disso, queridos e aceitos por seus alunos, estes podem aprender com esses professores muito mais do que o professor conscientemente pretende ensinar (MORALES, 2006, P.22).

De acordo com Alves (2004), “afeto, do latim affetare, quer dizer ir atrás” (p.20), e é exatamente esta a nossa reação. Quando o afeto nos contagia, de tal modo, queremos ir atrás do que tem nos instigado a conhecer através de um mestre que ensina com amor pelo que faz.

A professora Bruna completa, ainda, dizendo que um dia teve uma conversa amigável com a aluna. Ela disse que achava bom que Vitória se sentisse à vontade nas aulas, que gostava de conversar com ela e de ter um bom relacionamento. Declara que Vitória não tinha que parar de ser quem ela era, mas, na sala de aula, ela tinha que saber dosar um pouco nas brincadeiras, medir o momento para se extravasar e quando ela tinha de se conter para não atrapalhar as aulas. Depois desta conversa, a professora percebeu que Vitória a compreendeu e melhorou o comportamento nas aulas de teatro. 
Diante disso, percebemos que deve haver um equilíbrio no comportamento. O teatro proporciona uma liberdade de expressão por meio do nosso corpo e que, talvez, muitos alunos sejam imaturos para compreender que esse momento mais livre não significa que podem ser indisciplinados. A professora tem certa proximidade com a turma, e os alunos não percebem tanto uma barreira entre eles como talvez possam sentir com as professoras das demais disciplinas. As próprias atividades, em alguns momentos, também contribuem para que os alunos se extravasem, criando um tempo agradável de descontração com a turma. Mas todos esses fatores devem ser equilibrados para que os alunos não confundam a aula de teatro com o recreio. O professor deve situar os alunos de forma amigável para que não percam o foco de que aquele momento é uma aula e devem ter um bom comportamento para que as atividades fluam bem com a turma.

A professora Bruna leciona para os seus alunos os seguintes conteúdos: História do Teatro, Dança-Teatro, Stand up, Esquetes, Performance, Maquiagem, Figurino, Cenografia, a função de cada profissional dentro do teatro e jogos teatrais e dramáticos. É um vasto conteúdo da linguagem teatral que desenvolve diversas habilidades e pude notar que contribui para o desenvolvimento do aluno diagnosticado. Ela comenta que os alunos com laudos são extremamente participativos nas suas aulas e gostam muito de dar ideias.

O lugar do teatro na escola deve ser um espaço de encontro, onde seja possível trocar pensamentos, estabelecer outros níveis de relações humanas, de exposição pública de ideias, que possibilitam formalizar o convívio social. O lugar do teatro é um espaço de criação artística, mas também um espaço de convívio e troca (GAMA, 2010, p.17-18).

Acredito que os aspectos pedagógicos da linguagem teatral favorecem essa participação dos alunos e contribuem para que eles possam desenvolver a criatividade nas aulas, conforme apontado por Gama (2010). A socialização gerada a partir das práticas pedagógicas com o teatro possibilita que os alunos se sintam motivados a participarem com o grupo das atividades.

Em relação ao jogo teatral, a professora Bruna percebe que ele contribui muito para o processo de ensino e aprendizagem. Gama (2010), doutor em Artes, explica sobre o princípio dos jogos teatrais:

Com base nos princípios dos jogos teatrais, é possível a idealização de diversos experimentos artísticos que permitem conduzir o trabalho no sentido da criação de encenações. Procedimentos que fazem parte da sistematização de Jogos Teatrais, como a solução de problemas, o foco, a fiscalização, a estrutura dramática, quem, o quê, onde e o processo de avaliação podem ser utilizados, com o intuito de propor aos atores diversas formas de investigação e compreensão dos elementos que envolvem a linguagem teatral (p.14-15). 
Os aspectos abordados contribuem para que os alunos possam desenvolver diversas habilidades que irão favorecer a aprendizagem. Os processos criativos gerados por meio do jogo desempenham um papel fundamental no desenvolvimento do aluno não somente no âmbito educacional, mas também, na formação desse sujeito.

A professora Bruna acrescenta, ainda, que os professores de outras disciplinas veem no teatro um aliado para o ensino. Eles pedem sugestões e ela indica alguns jogos que possam favorecer o aprendizado do conteúdo.

Os professores, ao empregarem o jogo, podem perceber repercussões significativas no comportamento das crianças que ficam mais motivadas, inclusive, para frequentar a instituição, evoluem nas atitudes de cooperação, respeito mútuo, troca de pontos de vista, desenvolvem a autonomia, a confiança em si mesmas e se mostram mais curiosas e dispostas para outras aprendizagens (LIMA, 2008, p.146).

O trabalho interdisciplinar, realizado por meio do teatro, desperta nos alunos o interesse para adquirir novos saberes. O professor que utiliza desta linguagem vê os resultados de forma significativa tanto em relação à assimilação do conteúdo quanto a uma participação mais ativa dos estudantes.

Aprender fazendo é mais motivante do que somente participar de aulas expositivas e realizar a leitura dos materiais didáticos. Reconheço que estas e outras metodologias realizadas em sala de aula são relevantes para o ensino e precisam ser exercidas, mas vale enfatizar que quando o aluno aprende determinada matéria de uma forma mais dinâmica e lúdica, ele tem a predisposição para se interessar muito mais pelo que está sendo ensinado.

O trabalho interdisciplinar, realizado com as disciplinas regulares por meio do teatro, é uma estratégia didática que os professores devem se apropriar para que favoreçam um maior envolvimento da turma, gerando uma sintonia entre eles através do trabalho e também para um aprendizado mais criativo.

A professora comenta que os alunos tiveram melhorias no comportamento coletivo. Por eles terem a percepção sobre a importância de pertencerem a um grupo e neste contribuir uns com os outros, isso trouxe melhorias na sala de aula. Eles perceberam, ainda, que quando eles fazem alguma coisa que acaba atrapalhando os colegas e a aula, eles conseguem se disciplinar e não fazerem mais para que a turma não seja prejudicada.

Sobre o teatro como ação coletiva, o PCN Arte (1997) relata que, "com este critério, pretende-se avaliar se o aluno sabe organizar-se em grupo, ampliando as capacidades de ver e ouvir na interação com seus colegas, colaborando com respeito e solidariedade, permitindo a execução de uma obra conjunta" (p.65). Desta forma, percebemos que, por meio do teatro, os 
alunos aprenderam a trabalhar em equipe tendo uma postura colaborativa com o grupo de forma que os objetivos sejam alcançados e não haja distrações durante as atividades.

A professora relata, ainda, que alguns pais fazem questão que os filhos façam as aulas de teatro e que eles comentam que "os alunos estão sabendo se colocar melhor, falar melhor, têm uma noção de organização diferente; na sala, o aluno consegue se organizar melhor e organizar melhor o tempo". Toda essa mudança de comportamentos dos alunos é devido às atividades propostas pela professora.

O PCN Arte (1997) diz ainda que "no ensino fundamental, o aluno deve desenvolver um maior domínio do corpo, tornando-o expressivo, um melhor desempenho na verbalização, uma melhor capacidade para responder às situações emergentes e uma maior capacidade de organização e domínio de tempo" (p.59). Por esse motivo, mesmo que as atividades sejam feitas para os alunos como um todo, acredito que esses progressos se estendem para os alunos com Déficit de Aprendizagem também e contribuem para que haja um avanço no desenvolvimento dos alunos com esse transtorno.

\section{3 - Professora Cristina}

Cristina é professora de teatro em uma escola pública em Marilac-MG e leciona há 3 anos para o Ensino Fundamental das séries iniciais e finais. Ela dá aulas para seis alunos que têm o laudo de Déficit de Aprendizagem com faixa etária de 11 a 23 anos e tomam medicação devido ao transtorno. Alguns alunos, ela acompanha desde quando entrou na escola e os outros, há dois anos. Relatarei alguns casos que a professora descreveu.

Dentre os alunos, um tem 13 anos e cursa no $6^{\circ}$ ano, e o outro tem 16 anos e está no $9^{\circ}$ ano. Eles são repetentes e antes de a professora começar a dar aulas para eles, já tinham o Déficit de Aprendizagem. Eles fazem tratamento com uma psicóloga que relatou à professora que o transtorno é devido à família desestruturada e aos problemas sociais que eles vivenciam, e, por isso, eles se fecharam para o aprendizado.

Segundo a professora, um deles mora com a mãe que é ausente e negligente, e a avó é quem dá o suporte para o aluno. Sobre o comportamento deles nas outras disciplinas, eles não conseguem ficar muito tempo na sala de aula, pois sempre saem e ficam do lado de fora. $\mathrm{O}$ outro aluno não sabe ler nem escrever até hoje e praticamente não faz nada na sala. Eles são dispersos e, quando são cobrados, reagem de forma agressiva e violenta. Quando o conteúdo lecionado desperta interesse, um deles fica quieto num canto escutando o professor. De acordo 
com a psicóloga, os alunos apresentam esse comportamento como uma fuga devido ao transtorno.

Percebemos que os contextos familiares desses alunos são bem conturbados. Essa situação interfere diretamente no desenvolvimento escolar deles, repercutindo numa falha do processo de aprendizagem. Hoje, a professora Cristina percebe que os alunos estão mais abertos em relação a isso, mas que "não é um caminho fácil que você consegue da noite para o dia".

Sobre os outros alunos, um tem 22 anos e está no $8^{\circ}$ ano, outra tem 14 anos e está no $7^{\circ}$ ano e a outra aluna tem 17 anos, está no $8^{\circ}$ ano e tem problema de audição. Todos eles são repetentes e têm o Déficit de Aprendizagem há mais tempo, pois já nasceram com problemas neurológicos ou físicos.

Em relação ao relacionamento com a turma, a professora relata sobre os estudantes com problemas familiares, mostrando que eles não têm um bom convívio com a turma. Já os que têm problema neurológico e físico são entrosados e aceitos na classe. Essa diferença acontece, porque os alunos com problemas familiares são violentos e isso acaba afastando-os da turma.

\subsection{1 - Henrique: Exemplo de superação}

Henrique é o mais velho, com 23 anos e está no $8^{\circ}$ ano. Além de ter o Déficit de Aprendizagem devido a problemas neurológicos, ele também tem dificuldade de locomoção e problema de dicção. O pai foi embora para os Estados Unidos e o filho mora com a mãe. Ela tinha muito receio de que as pessoas rejeitassem o filho devido ao seu problema; e que, se dependesse dela, Henrique ficaria só dentro de casa. A professora diz que a escola ensinou a mãe a lidar com o problema do aluno. Apesar de toda sua limitação, a educadora relata que tem um apreço muito grande por ele, porque vê o quanto ele se esforça para fazer as aulas de teatro; além disso, completa que ele é um exemplo, pois se supera a cada dia, já se mostrou capaz, esforça-se para estar na escola, participa das atividades e sempre tem a ajuda dos colegas. A professora conta que ele gosta muito de teatro e quando tem alguma cena que tem que abaixar e levantar, ela não a muda, mas adapta de acordo com a realidade, pois ele sempre consegue fazer e se supera. Além desses problemas, Henrique tem uma doença degenerativa que, segundo a professora, a qualquer momento pode vir a falecer, mas ele não tem ciência sobre ela. A escola procura sempre incentivá-lo em tudo o que faz.

O PCN Arte (1997), diz que "é importante que o aluno sinta no professor um aliado do seu processo de criação, um professor que quer que ele cresça e se desenvolva, que se entusiasma quando seus alunos aprendem e os anima a enfrentar os desafios do processo 
artístico" (p.67). Percebemos que esse acolhimento que Henrique recebe é fundamental para que ele supere suas dificuldades e, apesar das limitações, ele possa se sentir motivado a se superar e a se desenvolver ainda mais no ambiente escolar.

Os alunos vivenciam problemas sociais muito sérios em casa, e realizar o trabalho com o teatro foi um desafio para a professora Cristina. Ela relata que quando iniciou o trabalho, os alunos eram muito dispersos e não conseguiam se concentram. Foi então que ela começou a se aproximar mais dos alunos e, através do diálogo, ela foi criando um relacionamento com eles e, aos poucos, entendendo a realidade de cada um. Ao perceber o contexto social dos alunos, a educadora começou a pensar que eles precisavam aprender a se concentrar em alguma coisa. Foi então que ela começou a ir pelo caminho da sensibilidade. A professora Cristina narra como iniciou esse processo:

Comecei a trabalhar concentração e relaxamento. Todos deitavam no colchonete e escutavam uma música. Eu pedia para eles dizerem o que aquela música falava de acordo com o contexto de cada um. Depois eles faziam uma cena sobre a música, em duplas. Trabalhava também com desenhos para que os alunos expressassem seus sentimentos; depois com a música e o texto.

A docente aplicava, ainda, jogos lúdicos para desenvolver a sensibilização. Os jogos envolviam o toque físico, pois, de acordo com a professora, eles não conseguiam se abraçar, devido ao histórico de violência e abuso em casa. Ela os instruía para que, se não quisessem se abraçar, poderia tocar no ombro ou pegar na mão. A professora comenta que eles sempre relacionavam o carinho com interesse sexual e teve um longo trabalho para explicar que o abraço do colega não era interesse sexual, mas uma demonstração de afeto. A educadora relata sobre a realidade social dos alunos:

Eles vêm de lares desestruturados. Desde criança, conviveram com a violência, com o alcoolismo, os pais mexiam com droga. Então tudo vai influenciando e eles se fecharam por causa desses problemas sociais vivenciados dentro de casa.

O início do trabalho da professora Cristina foi bem difícil devido à realidade que os alunos enfrentavam. Ela começou a introduzir a linguagem teatral e, aos poucos, os alunos foram desenvolvendo suas habilidades. A docente leciona os seguintes conteúdos com os alunos: História do Teatro, Interpretação de texto, Jogos teatrais, desenho e a música também, sempre buscando o caminho da sensibilização com eles.

A professora Cristina sempre realiza um espetáculo teatral com os alunos. Ela conta que, quando estavam preparando para realizar a apresentação, os dois alunos com problemas familiares perguntaram para ela o que poderiam fazer no espetáculo. Como eles não sabem ler, 
têm dificuldade de memorizar e assimilar as falas e são mais resistentes para apresentar em público, então, ela os incluiu na parte técnica. Eles realizaram o trabalho de sonoplastia no espetáculo soltando as músicas durante a apresentação, sempre com a professora do lado deles na mesa de som, a fim de orientá-los sobre as músicas e, assim, eles participaram do espetáculo. É bem interessante como a professora Cristina procura envolver todos os alunos nas atividades. Mesmo diante das dificuldades, ela atribuía alguma função para eles de forma que se sentissem úteis, contribuindo com o grupo no trabalho.

A educadora relata que o teatro promoveu resultados positivos com os alunos com problemas neurológicos e físicos, porque era trabalhada a concentração, para ajudar nas matérias de cálculo, e a interpretação de texto, com a disciplina de Língua Portuguesa. Os outros professores sempre pedem que a professora Cristina realize este trabalho interdisciplinar com os alunos e ainda ressaltam que eles tiveram melhorias com notas. Nesta interdisciplinaridade, ela complementa que já montou o espetáculo “Alice no País da Maravilhas” todo voltado para fórmulas matemáticas.

Verifico, com isso, que o trabalho interdisciplinar proporciona ótimos resultados no desempenho dos alunos, pois o teatro, utilizado como recurso pedagógico, é uma poderosa estratégia didática para que os alunos tenham uma melhor assimilação sobre os conteúdos das outras matérias.

A professora Cristina diz, ainda, que a direção da escola tem reconhecido os avanços do trabalho com o teatro. Ela conta que quando o teatro chegou à escola, era devido ao alto índice de evasão escolar. Segundo a educadora, o trabalho começou timidamente com uma aula por semana para cada turma, mas devido aos resultados positivos, a direção da escola solicitou à professora que aumentasse o número das aulas de teatro. Essa escola funciona com período integral, então os alunos estudam no período matutino e vespertino tendo aulas das disciplinas regulares e as aulas de teatro.

Sobre a influência do teatro com os alunos, a professora Cristina relatou que, quando sua aula flui bem, esta reflete diretamente no comportamento dos alunos em sala de aula, pois os outros professores comentam que eles ficam mais tranquilos. Sobre os alunos com problemas neurológicos e físicos, a docente disse que tiveram um avanço com eles devido ao trabalho com o teatro, pois eles melhoraram o raciocínio e a concentração.

Os pais também cometam sobre o trabalho. Ela disse que a mãe de Henrique sempre diz que o teatro faz bem pra ele. O pai do aluno de 17 anos, com dificuldade de locomoção, sempre o traz para as aulas teatro, porque vê que o filho gosta de participar. O reconhecimento da 
família dos alunos é fundamental tanto para avaliar os resultados quanto para motivar a professora Cristina a continuar desenvolvendo o trabalho.

Um outro fato interessante é que, em relação às disciplinas regulares, os alunos com problemas físicos e neurológicos apresentam mais vontade de aprender do que os outros dois alunos com problemas familiares.

Em relação à forma como o teatro reflete na vida pessoal dos alunos, a educadora relata que houve melhoras no comprometimento, na responsabilidade, na forma de expressão e na reflexão, e disse ainda que alguns alunos reconhecem que o teatro os tem ajudado a se desenvolverem, além disso, os demais estudantes sentem-se motivados a se interessarem pela arte.

Ela enfatiza que, a partir do momento em que há uma sensibilização, as pessoas se revelam no teatro e isso se reflete num todo. É um trabalho de superação diária e completa "eu sei que eu estou no caminho, que estou conseguindo, porque se não tivesse interesse, se não tivesse frutos, o trabalho não estava em andamento". Cristina aborda também em seu trabalho questões sociais, pois isso se reflete na vida pessoal deles. É interessante perceber que trazer a realidade dos alunos para serem estudadas por meio do teatro, contribui para que se tornem melhores como sujeitos.

Um outro ponto relevante é que os alunos que têm problemas neurológicos e físicos passaram a se aceitar melhor como pessoa, contribuindo para a melhora da autoestima, pois conseguem ter uma outra perspectiva sobre si. Mesmo com todas as dificuldades, por meio do teatro, os alunos se esforçam para aprender e conseguir fazer as atividades. Cada avanço é uma vitória dessa professora que, com muita paciência, esforço e afeto tem conseguido ótimos resultados com o trabalho.

Neste capítulo foi abordado sobre o perfil dos alunos, com destaque para aqueles que se sobressaíram, nos relatos das professoras. Cada realidade é diferente e os alunos possuem características peculiares. O mais interessante é perceber como as professoras desenvolveram os aspectos pertinentes à linguagem teatral com os estudantes. Foram muitas dificuldades enfrentadas no percurso, mas em cada desafio, uma vitória diária.

A sensibilidade, o afeto, a sabedoria, o respeito e a persistência são qualidades que percebi nestas professoras ao trabalhar o teatro nas escolas com alunos diagnosticados com o Déficit de Aprendizagem.

Nos estudantes, notei a força de vontade, a dedicação, o apreço, o envolvimento e a superação que, mesmo diante do seu contexto de vida, muitas vezes conturbado, viram no teatro 
uma forma de se desenvolverem não somente na escola, mas levaram consigo todo o conhecimento adquirido para a vida.

Gama (2010) diz que "teatro exige gente que gosta de pensar, de se aventurar pelos caminhos do conhecimento" (p.3) e, em todos os perfis que foram destacados, percebemos a instigação pelo fazer teatral.

Descreverei de forma mais pontual, minhas impressões sobre este trabalho nas considerações finais. 


\section{CONSIDERAÇÕES FINAIS}

A problemática que gira em torno do aumento de diagnósticos devido à dificuldade de aprendizagem nos leva a pensar em muitas questões. Há poucos anos, não víamos tantos laudos sendo entregues nas escolas, como temos visto atualmente.

Diante disso, constata-se que o trabalho do professor de teatro é um desafio diário em relação à escola, à família, aos alunos e consigo mesmo. A dedicação, o empenho e, principalmente, o amor do arte-educador pelo que faz contribuem para que muitas barreiras sejam quebradas e muitas vitórias sejam conquistadas. Apesar de todas as limitações, o professor busca, por meio da arte, em especial do teatro, desenvolver um trabalho que possa ir ao encontro da educação, formando não somente alunos, mas cidadãos que, na sua singularidade, têm muito a oferecer no meio em que estão inseridos. Não podemos ter um olhar julgador sobre o sistema educacional, pois, apesar de todas as falhas que inevitavelmente acontecem, a escola e toda a equipe pedagógica procuram desempenhar um trabalho que favoreça a aprendizagem do aluno.

A escola e a família procuram seguir as orientações prescritas nos laudos de forma que auxiliem os alunos nas suas dificuldades. Algumas famílias atuam em parceria com a escola de forma que possam dar a assistência necessária no acompanhamento do aluno. Outras, devido à falta de estrutura familiar, não dão a atenção necessária para o problema. Além de a escola realizar um trabalho diferenciado com esses alunos, ela se vê no papel de conscientizar a família sobre o problema.

Oliveira, Bittencourt e Carmo (2008) relatam que, “da mesma forma que a família é o pilar da construção de vínculos saudáveis entre seus membros, as famílias disfuncionais podem conduzir normas desviantes pela forma de comportamento dos responsáveis para com seus filhos" (p.9). O apoio da família é fundamental para que se crie um ambiente favorável para o aprendizado. Se ela entende que o teatro pode proporcionar esse desenvolvimento, o aluno se sente motivado a participar das aulas e a se empenhar nas atividades. A professora Ana relata sobre a importância do reconhecimento dos pais com o trabalho dizendo que, em muitos lugares, os pais não apoiam, não gostam e criam um preconceito sobre o teatro sem ao menos entender qual a dinâmica de trabalho.

Por trás do perfil de um aluno, há uma história que muitas vezes são cheias de angústias. Cada família tem uma história de vida que, às vezes, por falta de conhecimento, contribuiu para que o aluno seja resistente ao aprendizado ou, em outros casos, é devido a fatores neurológicos. 
Mas em todos os casos, o sujeito tem capacidades e pode desenvolver habilidades que, por meio da arte e de uma aula dinâmica e diferenciada, ele se sinta mais livre para desenvolvê-las.

Sobre os alunos diagnosticados, a professora Bruna diz que cada indivíduo será diferente do outro independentemente do laudo que ele tiver, e que não podemos generalizar, porque cada caso é diferente. Apesar das dificuldades, eles devem ser tratados de forma igual. Muitas vezes, esses alunos são rotulados como "fracos" e acredito que esta postura deve ser repensada, pois, se ele não corresponde a uma determinada expectativa, seja da escola, do professor ou até mesmo da família, é porque ele tem dificuldades que devem ser levadas em conta.

A grande questão é que julga-se o aluno por aquilo que ele tem dificuldade, mas não lhe são dados os recursos que possam ser trabalhos para que ele melhore e se desenvolva. Nesse sentido, constata-se que a linguagem teatral pode favorecer, e muito, que esse aluno adquira e aprimore novas habilidades, oportunizando, assim, um melhor rendimento tanto na escola, como na sua singularidade.

A professora Ana coloca algumas das suas dificuldades dizendo que, às vezes, esses alunos se misturam na turma e dessa forma não se dá uma atenção tão específica para eles, pois as aulas são realizadas com a turma de maneira geral, e os alunos diagnosticados participam das atividades juntamente com os outros. A professora expressa essa preocupação, mas, ao mesmo tempo, ela como educadora, tem que dar atenção para os demais alunos também, senão eles perceberiam um tratamento diferente e poderiam se sentir menos assistidos por ela. Desta forma, nota-se que o professor deve ter uma sensibilidade sobre cada situação e saber ter equilíbrio ao lidar com a turma.

A professora Cristina aborda que muitas vezes pensa-se que o caminho do ensino deve ser de forma teórica e formal, mas existem outras vertentes que devem ser analisadas. Devemos conhecer o aluno, qual é a sua realidade e como podemos nos aproximar dele de forma que, através do vínculo criado, o processo de ensino e aprendizagem seja mais eficaz. De acordo com ela, o teatro

tem essa possibilidade, porque através dele as pessoas se mostram e, a partir desta abertura que o teatro dá, nessa sensibilização, somos capazes de conhecer um pouquinho da realidade do aluno e ir ao encontro da sua necessidade. Eu sinto no teatro essa abertura, essa possibilidade. Quando começamos a conversar com o aluno, passamos a entendê-lo. Se não há um diálogo, se não existir o conhecimento, não vai existir a troca.

É necessário identificar qual será o melhor caminho para o ensino do aluno. O teatro proporciona muitas possibilidades que podemos desenvolver com eles, de forma que possam superar suas limitações e aprimorar suas habilidades. 
Dessa forma, o teatro propicia grande benefício ao aluno contribuindo para a sua educação. Por meio da linguagem teatral, os alunos são instigados a se desenvolverem no ambiente educacional. Pertencer a um grupo e estar continuamente com ele promove o trabalho em equipe e o sentimento de que cada um tem a sua importância, e todos trabalham de forma que possam alcançar objetivos em comum. Há também o desenvolvimento do sujeito na sua singularidade e isso se repercute não só na escola, mas na vida como um todo.

Oliveira e Stolz (2010) entendem que o teatro contribui para desenvolver a noção espacial, atenção e memorização aprimorando a linguagem corporal e verbal, sendo necessária a interação com o grupo e com os aspectos culturais. Com isso, o aluno será instigado em áreas da cognição, do afeto, sociabilização e do trabalho corporal por meio da repetição de exercícios e da assimilação sobre os elementos teatrais, contribuindo para o processo de aprendizagem.

O conhecimento é construído à medida que o aluno é estimulado. O professor de teatro desempenha um papel fundamental na instigação dos estudantes para que possam se dedicar às atividades, refletindo sobre o que estão fazendo. Desta forma, o aluno compreende o objetivo do exercício e atua de forma colaborativa juntamente com o grupo.

No entanto, é importante destacar que não se tem a pretensão de afirmar que, por meio do teatro ou qualquer outra forma artística realizada na escola, esses serão capazes de solucionar todos os problemas do sujeito na sua vivência pessoal ou educacional. Mas não podemos negar que a arte é de fundamental relevância para a vida, pois ela contribui para a formação da subjetividade de pessoas que consigam ter segurança em se situar na sociedade de forma integral, levando em consideração seus aspectos afetivos e cognitivos (OLIVEIRA e STOLZ, 2010).

O papel da escola vai além de proporcionar que o estudante conclua o ciclo básico. A instituição contribui, principalmente, para a formação humanitária desse aluno, como foi abordado no primeiro capítulo. Percebemos que a linguagem teatral é uma das metodologias que, com muito dinamismo, proporciona essa formação ao sujeito. Em muitos ambientes educacionais, há um descrédito sobre o trabalho artístico e, muitas vezes, a Arte é tida como uma disciplina secundária. O componente artístico é fundamental para que haja um desenvolvimento integral do aluno e, assim como as demais disciplinas, ela deve ser valorizada.

Nos casos relatados, por meio das entrevistas com as três professoras de teatro, percebi que, em sua grande maioria, os alunos com Déficit de Aprendizagem desenvolveram muitas 
habilidades, superaram dificuldades e tiveram resultados positivos por meio da linguagem teatral trabalhada no ambiente educacional.

Não se pode afirmar com absoluta certeza que esta conclusão se estende de forma generalizada, pois, para isso, seriam necessários estudos mais aprofundados sobre a questão. Mas pelos relatos que obtive das professoras, os resultados foram animadores. Apesar das dificuldades tanto em relação à escola, à família, ao professor, quanto em relação às limitações do próprio aluno, percebo que é possível realizar esse trabalho utilizando os recursos pedagógicos e artísticos que a linguagem teatral oferece e, de forma progressiva, gerar um bom resultado com os alunos com Déficit de Aprendizagem. 


\section{REFERÊNCIAS}

ALENCAR, Eunice; FLEITH, Denise. Criatividade. Múltiplas perspectivas. 3a. ed. Brasília: Editora UnB, 2009. v. 1. 220p.

ALVES, Rubem. O desejo de ensinar e a arte de aprender. Campinas: Fundação, 2004.

BARBOSA, Ana Mae Tavares Bastos. Teoria e prática da educação artística. São Paulo: Cultrix, 1975.

BRASIL, Lei no 9394 - 20 de dezembro de 1996. Lei de Diretrizes e Bases da Educação Nacional. Diário Oficial da República federativa do Brasil, Brasília, 23 de dezembro de 1996.

BRASIL. Secretaria de Educação Fundamental. Parâmetros curriculares nacionais: arte / Secretaria de Educação Fundamental. - Brasília: MEC/SEF, 1997.

FERNÁNDEZ, Alicia. A Inteligência aprisionada. Porto Alegre: Artmed, 1991.

GAMA, Joaquim. Teatro: uma experiência criativa. In: D. Tozzi, M. M. Costa, T. Honório (organizadores). Teatro e Dança: repertórios para a educação. São Paulo: Perspectivas, vol.3, 2010.

ICLE, Gilberto. Para apresentar a Performance à Educação. Educação e Realidade, v. 35, p. 11 22, 2010.

LIMA, José Milton de. O jogo como recurso pedagógico no contexto educacional. 2008.

LINO, Elivania. Teatro de formas animadas na sala de aula: um recurso pedagógico para o desenvolvimento do ensino de teatro. 2012. 50 f. Monografia (Licenciatura em Teatro) Universidade de Brasília, Brasília, 2012.

MORALES, Pedro. A relação professor-aluno: o que é, como se faz. 6. ed. São Paulo: Loyola, 2006.

OLIVEIRA, Elias; BITTENCOURT, Leilane; CARMO, Aila. "A importância da família na prevenção do uso de drogas entre crianças e adolescentes: papel materno." SMAD. Revista eletrônica saúde mental álcool e drogas 4.2 (2008).

OLIVEIRA, M. E.; STOLTZ, T. Teatro na escola: considerações a partir de Vygotsky. Curitiba: Editora UFPR, 2010.

PAÍN, Sara. Diagnóstico e tratamento dos problemas de aprendizagem. Porto Alegre: Artmed, 2003.

PRADOS, Juliana; MERÍSIO, Paulo. O Melodrama como Fonte e Recurso Pedagógico na Escola e na Universidade. Horizonte Científico (Uberlândia), v. 1, p. 1-19, 2009. 
ROBINSON, Ken. O elemento chave: Descubra onde a paixão se encontra com seu talento e maximize seu potencial. Rio de Janeiro: Ediouro, 2010.

SCARPATO, Marta. Dança educativa: um fato em escolas de São Paulo. Cadernos Cedes, ano XXI, no 53, abril/2001.

SILVA, Sueli Probio da. Pedagogia do teatro: perspectivas de aprendizagens, através das atividades teatrais na escola. Dissertação de monografia Barreto/SP. UnB, 2012.

SMITH, Corinne; STRICK, Lisa. Dificuldades de Aprendizagem de A a Z. Penso Editora, 2012.

TOPCZEWSKI, Abram. Aprendizagem e suas desabilidades: como lidar? São Paulo: Casa do Psicólogo, 2000.

VIEIRA, Marcilio. O corpo como linguagem na dança-teatro de Pina Bausch. Interface (Natal), v. 2, p. 111-118, 2005.

VYGOTSKY, L.S. Formação social da mente. 4. ed. São Paulo: Martins Fontes, 1991. 